\title{
VLIV OBSAHU CAO NA SPECIFICKÉ VLASTNOSTI LCC, ULCC A NCC
}

\section{INFLUENCE OF CAO CONTENT ON SPECIFIC LCC, ULCC AND NCC PROPERTIES}

\author{
David Zemánek ${ }^{*}, 1$, Lenka Nevřivová ${ }^{1}$
}

"zemanek.d@fce.vutbr.cz

${ }^{1}$ Vysoké učení technické v Brně, Fakulta stavební, Ústav technologie stavebních hmot a dílců, Veveři 95, 60200 Brno

\begin{abstract}
Abstrakt
Žárobetony jsou stále více používaným žárovzdorným materiálem s rostoucí oblibou v různých aplikacích. Tři typy žárobetonů (LCC, ULCC a NCC) byly navrženy a testovány. Jednou z důležitých vlastností, která je u taveninami napadených žáromateriálů sledovaná, je korozní odolnost. Pro prvotní testování byla využita korozní kelímková zkouška a jako korozní činidlo byl v této práci použit uhličitan draselný. Vliv koroze byl posuzován pomocí skenovacího elektronového mikroskopu (SEM) a rentgenové difrakce (XRD). Výsledky potvrzují, že vyšší množství $\mathrm{CaO}$ z hlinitanového cementu obsažené v žárobetonu může vést k tvorbě nízkotavitelných eutektik snižujících korozivzdornost. Korozní odolnost žárobetonů je možné zvýšit snížením obsahu oxidu vápenatého nebo úplnou náhradou hlinitanového cementu.
\end{abstract}

\section{Klíčová slova}

Žárobeton, korozní odolnost, oxid vápenatý

\begin{abstract}
Castables are widely used refractory materials with variable applications. Three types of castables (low cement, ultra-low cement and no cement) were tested to compare their specific properties. Also, corrosion resistance test as an important factor influencing castables design was carried out. Potassium carbonate was used as a corrosive medium using static crucible method. The corrosion mechanisms were evaluated by Scanning Electron Microscopy (SEM) and X-ray Diffraction (XRD). The results confirmed that the presence of higher amount of calcium oxide from the Calcium Aluminate Cement (CAC) leads to formation of calcite and anorthite. The corrosion resistance was improved with decreasing or replacing the hydraulic bond.
\end{abstract}

Key words

Castables, corrosion resistance, calcium oxide

\section{1 ÚVOD}

Použití mikrosiliky přineslo v posledních desetiletích zásadní revoluci ve vývoji a výrobě žárobetonů. Tyto typy mikroplniv s velikostí částic pod $1 \mu \mathrm{m}$ měly významný vliv na distribuci částic a fyzikální vlastnosti žárobetonu. Použití mikroplniv vedlo také k novým návrhům žárobetonů se sníženým obsahem záměsové vody a zvýšenou hutností [1], [2].

Současně s vývojem sortimentu žárobetonů s obsahem mikrosiliky v matrici se rozšiřovala nabídka dispergačních činidel a nových typů kalcinovaného a reaktivního oxidu hlinitého. Tím došlo ke vzniku nových typů žárobetonů, označované jako LCC a ULCC s nízkým a ultranízkým obsahem cementu (méně než 7 \% pro typ LCC a méně než $3 \%$ pro typ ULCC), související s obsahem oxidu vápenatého - LCC (1,0-2,5\% CaO), ultranízkocementové žárobetony ULCC $(0,2-1 \% \mathrm{CaO})$. Vlastnosti těchto žárobetonů dosahovaly nebo i převyšovaly úroveň pálených tvarových materiálů v pevnosti, pórovitosti, otěruvzdornosti při velmi dobré objemové stálosti po vypálení na teplotu použití $[2,3]$. Navzdory těmto významným pokrokům v kvalitě žárobetonů stále existuje několik problémů ve srovnání s tvarovanými výrobky:

- proces sušení a ohřevu na pracovní teplotu - je nutné rozložit hydratovaný hlinitan vápenatý $\mathrm{C}_{3} \mathrm{AH}_{6}$ (teplota rozkladu cca $320{ }^{\circ} \mathrm{C}$ ), což vede k vysokému tlaku par a s tím spojenému riziku destrukce agregátu; 
- $\quad$ i malý obsah oxidu vápenatého v žáruvzdorném materiálu vede $\mathrm{k}$ tvorbě sloučenin vznikajících ohřevem nad $900{ }^{\circ} \mathrm{C}$ v systému $\mathrm{CaO}-\mathrm{Al}_{2} \mathrm{O}_{3}-\mathrm{SiO}_{2}$ s eutektikem při teplotě kolem $1220^{\circ} \mathrm{C}$.

Z těchto důvodů byly zkoumány nové typy vazeb. Nejprve byl hlinitanový cement nahrazen hydratovaným kysličníkem hlinitým v kombinaci s reaktivním kysličníkem hlinitým. Tato vazba je na suroviny poměrně nákladná, proto je vhodná pro vysoce kvalitní materiály [3,4]. Dalším krokem bylo zkoušení v jiných odvětvích známé metody sol-gel, která se začala rozvíjet dříve ve slévárenství. Použití této metody umožňuje z navržených směsí odstranit většinu oxidu vápenatého obsaženého v CAC (hlinitanový cement) a tím celou směs převést na dvoufázový systém $\mathrm{Al}_{2} \mathrm{O}_{3}-\mathrm{SiO}_{2}$. Literatura také popisuje rychlejší proces sušení, který je možný díky absenci rozkládajících se hydrátů během zahřívání. Dochází tak pouze k výparu záměsové vody, která se tak odpařuje při nízkých teplotách do $120^{\circ} \mathrm{C}$. Další výpal materiálu nebo ohřev není ohrožen vznikajícím tlaky páry [1], [3], [5]. Kromě fyzikálních, mechanických a žárových vlastností je při aplikaci důležitá korozní odolnost. Obecně existují dva základní typy koroze.

Mechanická koroze, lépe známá jako abraze, je jedním z úskalí žárobetonů používaných v různých aplikacích, zejména ve vysokých pecích, předehřívačích a chladičích, různých částech spaloven, hliníkárnách atd., kde se typická teploty vyzdívky pohybují v rozmezí $800-1100^{\circ} \mathrm{C}$. Bylo popsáno [4], že distribuce velikosti zrn a zkušební teplota mají různý vliv na otěruvzdornost žárobetonů při stejných vstupních parametrech (chemické složení, obsah CAC a záměsová voda). Měření otěruvzdornosti je nejčastěji prováděno podle norem ASTM C704 nebo EN932-20, což jsou normy pro zkoušení při pokojové teplotě [4], [5].

Chemická koroze žáruvzdorných materiálů je definována jako opotřebení ztrátou tloušt'ky a hmoty z exponované strany žáruvzdorného materiálu v důsledku chemického napadení korodujícím médiem. Podstatným bodem je, že korozní reakce probíhají ve směru k lokální chemické rovnováze. Proto se k analýze korozních odolnosti a k návrhu žárobetonů pro minimalizaci míry koroze a opotřebení používají fázové diagramy [5], [8].

\section{METODIKA}

Na základě předchozího zkoumání bylo navrženo pět receptur se stejným hrubým ostřivem frakce 3-5 mm. Byla vyvržena jedna nízkocementová receptura (LCC), dvě ultra-nízkocementové receptura (ULCC1, ULCC2) a dvě bezcementové receptury (NCC1, NCC2), jemnozrnná matrice byla ve shodě s předchozím výzkumem [6]. Použité hrubé ostřivo je na bázi andalusitu - aluminosilikát, který se nachází v metamorfovaných horninách. Producentem je společnost IMERYS, která nabízí celkem 4 druhy andalusitů s různou chemickou čistotou viz Tab. 1 [7]. Z nabídky byl vybrán Durandal D60 kvůli nejnižším obsahům alkálií a taviv.

Tab. 1 Chemické složení dostupných andalusitů od výrobce IMERYS [\% hmot.].

\begin{tabular}{ccccc}
\hline Označení andalusitu & $\mathbf{A l}_{2} \mathbf{O}_{3}$ & $\mathbf{F e}_{2} \mathbf{O}_{3}$ & $\mathbf{K}_{\mathbf{2}} \mathbf{O}+\mathbf{N a}_{2} \mathbf{O}$ & $\mathbf{T i O}_{2}+\mathbf{C a O}+\mathbf{M g O}$ \\
\hline Kerphalite KF & 60,8 & 0,45 & 0,25 & 0,30 \\
Durandal D60 & 60,8 & 0,42 & 0,20 & 0,25 \\
Randalusite Premium & 60,5 & 0,62 & 0,20 & 0,30 \\
Standard Andalusite & 59,3 & 0,72 & 0,32 & 0,38 \\
\hline
\end{tabular}

Receptury jsou uvedeny v následující Tab. 2. Receptury byly navrženy podle Andreasenova modelu distribuce částic s koeficientem q=0,23. Při vývoji nebyly použity žádné deflokulanty. Pro receptury nízkocementových a ultra-nízkocementových žárobetonů byl použit hlinitanový cement CA14M od výrobce Almatis. Pro obě bezcementové receptury byla použita metoda sol-gel. Na základě předchozího výzkumu [8] byly vybrány dvě gelační činidla - kausticky pálené MgO (receptura NCC1) a komerční produkt FFB1467 (receptura NCC2) od výrobce Zschimmer-Schwarz. Použitá koloidní silika měla velikost částic d50 = 50 nm a koncentraci $30 \%, \mathrm{pH}$ 9,5 a byla stabilizovaná $\mathrm{Na}^{+}$ionty. 
Tab. 2 Složení receptur a tokové vlastnosti.

\begin{tabular}{cccccc}
\hline Složení & LCC & ULCC1 & ULCC2 & NCC1 & NCC2 \\
\hline D.D60 3-5 mm & 68 & 68 & 68 & 68 & 68 \\
JMX & 22 & 22 & 22 & 22 & 22 \\
Voda & 3,5 & 4,0 & 3,7 & 5,1 & 5,0 \\
Koloidní silika & - & - & - & 5 & 5 \\
Hlinitanový cem. & 5 & 2 & 2 & - & - \\
Gelační činidlo & - & - & - & 0,2 & 0,2 \\
Self flow [mm] & 25 & 25 & 30 & 25 & 30 \\
Vibration flow [mm] & 170 & 180 & 170 & 160 & 170 \\
\hline
\end{tabular}

Legenda: D.D60 - Durandal D60, JMX - jemnozrnný matrix, selfflow - rozlití po zvednutí kužele, vibration flow - rozlití po 30 s vibrace

Připravené receptury byly 15 minut homogenizovány s následným př́́davkem vody (a u NCC také koloidní siliky) a byly 5 minut za vlhka míchány v laboratorním mísiči. Self-flow a vibration-flow uvedené $\mathrm{v}$ Tab. 2 byly měřeny podle normy ASTM C 1446-19. Žárobetonové směsi pak byly následně odlity do kovových forem o rozměrech 40x40x160 mm 100x100x100 mm. Vzorky byly následně uloženy po dobu 24 hodin v laboratorních podmínkách pod igelitovou fólií. Vzorky byly následně vysušeny v laboratorní sušárně při teplotě $110^{\circ} \mathrm{C}$ pod dobu 24 hodin. Vzorky byly poté vypáleny v laboratorní peci na $1500{ }^{\circ} \mathrm{C}$ (nárůst teploty $4{ }^{\circ} \mathrm{C} / \mathrm{min}$ a výdrž 300 min na maximální teplotě).

Objemová hmotnost, nasákavost, zdánlivá pórovitost, pevnost v tlaku a pevnost v tahu byly provedeny po vysušení i po výpalu podle př́slušných norem (ČSN EN 993-1:1995). Trvalé délkové změny po výpalu byly stanoveny podle normy ČSN EN 993-10:1997. Dále byla provedena únosnost v žáru (ČSN ISO 1893:2007), teplotní dilatometrická analýza (ČSN EN 993-19:2004). Chemické složení bylo stanoveno podle normy ČSN EN ISO 21 587. Pro zkoumání vnitřní struktury byl použit skenovací elektronový mikroskop (SEM) s EDX sondou (Tescan MIRA3). Korozní zkoušky byly provedeny podle normy CEN/TS 15418. Použité korozní činidlo bylo $20 \mathrm{~g}$ uhličitanu draselného, korozní kelímky byly poté vypáleny na teploty $950{ }^{\circ} \mathrm{C}$ s výdrží na maximální teplotě 5 hodin.

\section{VYHODNOCENÍ VÝSLEDKŮ A DISKUZE}

Experimentální práce byla zaměřena na srovnání různých druhů žárovzdorných betonů se zaměžením na fyzikální, mechanické a korozní vlastnosti po výpalu. V následující Tab. 3 je uvedeno výsledné chemické složení žárobetonů po výpalu. Receptury založené na metodě sol-gel jsou podle normy ASTM C401-12 charakterizovány obsahem $\mathrm{CaO}$ nižším než $0,2 \%$ - tento požadavek byl splněn a žárobetony je možné jako bezcementové označovat. Stejný př́pad je označení ultra-nízkocementových žárobetonů - podle normy musí splňovat obsah CaO nižší než 1,0 \% - i v tomto prípadě byla podmínka normy splněna.

Tab. 3 Chemické složení žárobetonů po výpalu na teplotu $1500{ }^{\circ} \mathrm{C}[\%]$.

\begin{tabular}{ccccccccc}
\hline Receptura & $\mathbf{S i O}_{2}$ & $\mathbf{A l}_{2} \mathbf{O}_{3}$ & $\mathbf{T i O}_{2}$ & $\mathbf{F e}_{2} \mathbf{O}_{3}$ & $\mathbf{C a O}$ & $\mathbf{M g O}$ & $\mathbf{K}_{2} \mathbf{O}$ & $\mathbf{N a}_{2} \mathbf{O}$ \\
\hline LCC & 32,47 & 64,68 & 0,15 & 0,57 & 1,52 & 0,10 & 0,20 & 0,21 \\
ULCC1 & 30,13 & 67,83 & 0,10 & 0,52 & 0,72 & 0,11 & 0,24 & 0,16 \\
ULCC2 & 30,58 & 67,67 & 0,10 & 0,42 & 0,59 & 0,11 & 0,20 & 0,23 \\
NCC1 & 33,00 & 65,03 & 0,10 & 0,47 & 0,18 & 0,33 & 0,25 & 0,54 \\
NCC2 & 31,70 & 66,53 & 0,12 & 0,39 & 0,19 & 0,32 & 0,18 & 0,46 \\
\hline
\end{tabular}


V následující Tab. 4 je uvedena objemová hmotnost, nasákavost, zdánlivá pórovitost, zdánlivá hustota a trvalé délkové změny po výpalu na $1500{ }^{\circ} \mathrm{C}$. Výsledky ukazují, že se objemová hmotnost výrazně liší od použitého pojiva, přičemž nejvyšší hodnoty dosahuje ULCC1. Další naměřené parametry pak korespondují s objemovou hmotností. Zdánlivá pórovitost, která je jedním z klíčových parametrů pro korozní odolnost, je nejnižší právě u již zmíněného bezcementového žárobetonu NCC1. Poměrně významné rozdíly je možné pozorovat i mezi dvěma cementem pojenými třídami (LCC a ULCC) - zdánlivá pórovitost je u LCC žárobetonu o 3-4 \% vyšší, než je tomu u ULCC žárobetonů, s čímž úzce souvisí výsledné trvalé délkové změny, které jsou u LCC žárobetonu nejnižší.

Tab. 4 Fyzikální parametry žárobetonů po výpalu na teplotu $1500{ }^{\circ} \mathrm{C}$.

\begin{tabular}{cccccc}
\hline Receptura & OH $\left[\mathbf{k g} \cdot \mathbf{m}^{-3}\right]$ & NV [\%] & ZP [\%] & ZH $\left[\mathbf{k g} \cdot \mathbf{m}^{-3}\right]$ & TDZ [\%] \\
\hline LCC & 2500 & 6,84 & 17,13 & 3020 & $+0,73$ \\
ULCC1 & 2670 & 4,93 & 13,17 & 3070 & $+0,89$ \\
ULCC2 & 2630 & 5,37 & 14,11 & 3060 & $+0,81$ \\
NCC1 & 2640 & 4,52 & 11,93 & 3000 & $+1,07$ \\
NCC2 & 2540 & 6,15 & 15,75 & 3040 & $+1,14$ \\
\hline
\end{tabular}

Legenda: $O H$ - objemová hmotnost, $N V$ - nasákavost, $Z P-$ zdánlivá pórovitost, $Z H-z$ dánlivá hustota, TDZ trvalé délkové změny v žáru

Na Obr. 1 jsou uvedeny pevnost v tlaku (CCS) a pevnosti v tahu za ohybu (CMOR) po výpalu na $1500{ }^{\circ} \mathrm{C}$. Na základě výsledků můžeme tvrdit, že žárobetony založené na metodě sol-gel dosahují stejným případně lepších hodnot v porovnání s LCC a ULCC žárobetony. Výsledky pevností v tlaku korelují s hodnotami zdánlivé pórovitosti, kdy opět bylo dosaženo nevyšších hodnot u bezcementového žárobetonu na bázi sol-gel (CCS 47.1 MPa a CMOR 5,6 MPa). Při porovnání bezcementových žárobetonů na bázi sol-gel je v př́ípadě gelačního činidla kaustického $\mathrm{MgO}(\mathrm{NCC} 1)$ dosaženo lepších fyzikálních a mechanických parametrů oproti komerčnímu produktu FFB1467.

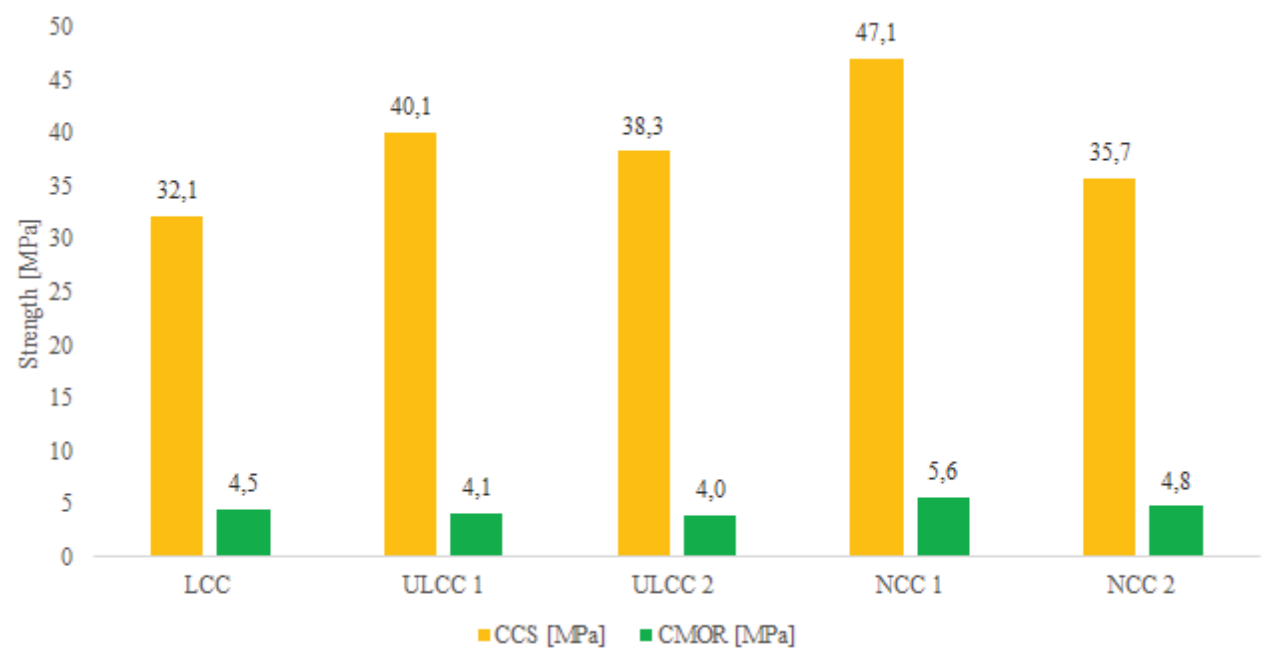

Obr. 1 Pevnost v tlaku (CCS) a pevnost v tahu za ohybu (CMOR) testovaných žárobetonů.

Následující Obr. 2 zobrazuje únosnost v žáru jednotlivých žárobetonů. Hodnota $\mathrm{T}_{0.5}$ je definována jako teplota, při které je dosaženo smrštění o hodnotě 0,5 \% měřené od bodu maximální teplotní dilatace a může reprezentovat počátek měknutí materiálu [9]. Nejvyšší únosnost v žáru byla stanovena pro LCC žárobeton $\left(\mathrm{T}_{0.5}=1698{ }^{\circ} \mathrm{C}\right)$, následuje ULCC1 žárobeton, u kterého je patrná nižší teplotní dilatace, která je způsobená nižším obsahem hlinitanového cementu. Další testované žárobetony vykazují v průměru o $40{ }^{\circ} \mathrm{C}$ nižší únosnost v žáru. 


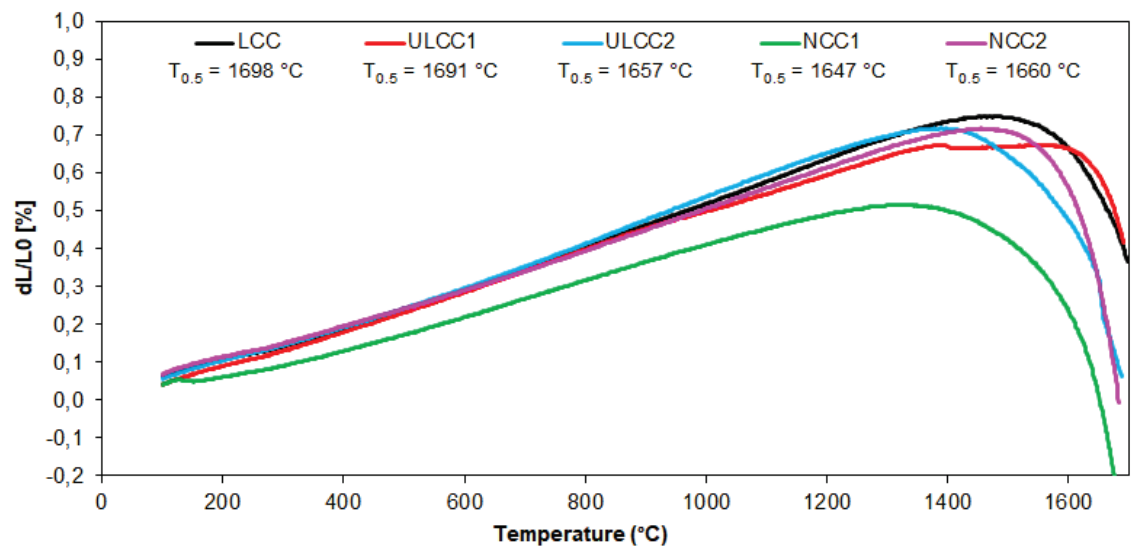

Obr. 2 Únosnost v žáru zkoušených žárobetonů.

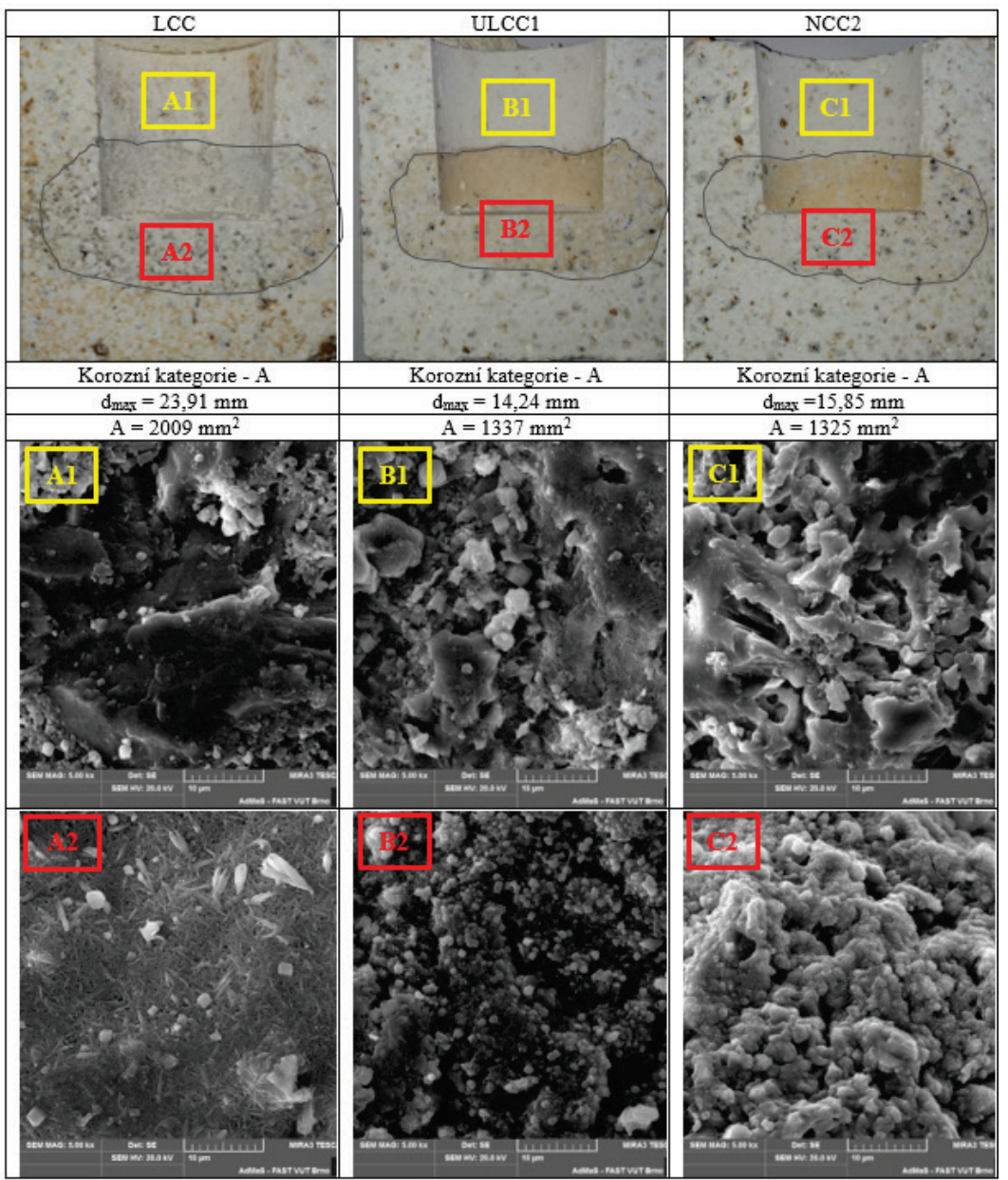

Obr. 3 Korozní odolnost - kelímková zkouška. 
Na základě vizuálního posouzení korozních kelímků uvedených na Obr. 3 je možné jednotlivé žárobetony zařadit do kategorie napadené (attacked - A) podle normy CEN/TS 15418 [10]. V závislosti na hloubce a ploše penetrace taveninou $\mathrm{K}_{2} \mathrm{CO}_{3}$ je nejvíce napadeným žárobetonem LCC. NCC2 a ULCC1 naproti tomu vykazují o $31 \%$, respektive 34 \% nižší penetrovanou plochu. Na snímcích SEM je možné pozorovat vyšší množství amorfní fáze $\mathrm{u}$ všech tří žárobetonů v jejich nekorodovaných částech. Naproti tomu je v korodovaných částech možné vidět nižší obsah amorfní fáze, spíše jsou zřetelné krystalické fáze, zejména mullit.

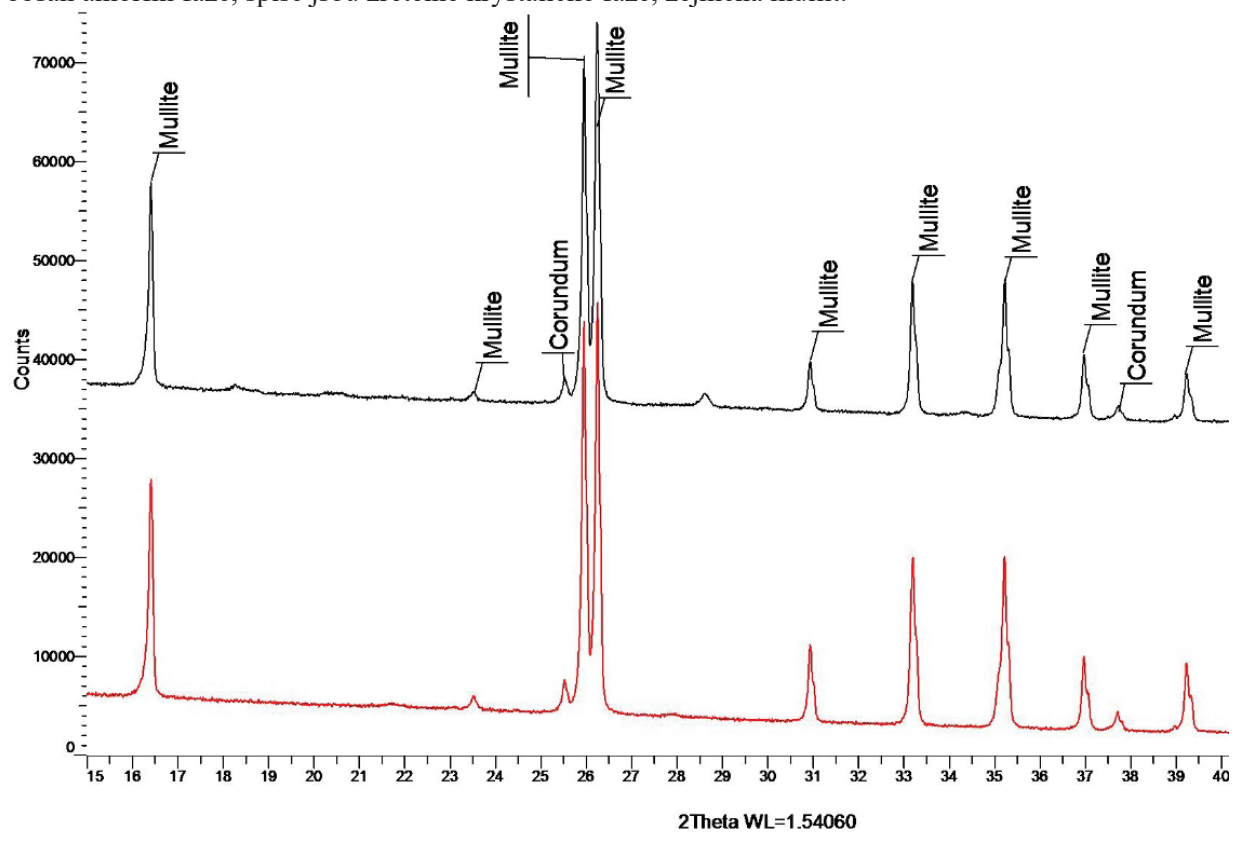

Obr. 4 ULCC - difraktogramy (červená - nekorodovaná část, černá - korodovaná část).

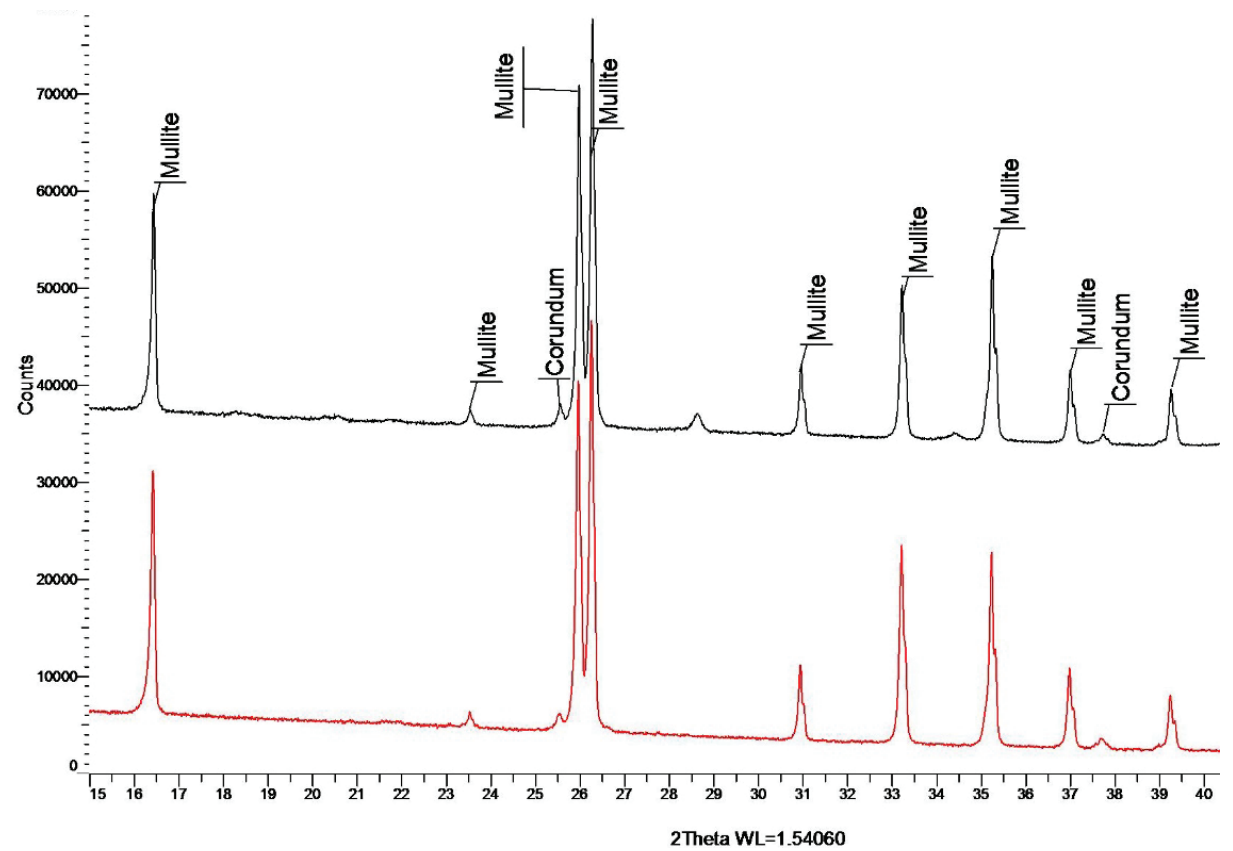

Obr. 5 NCC2 - difraktogramy (červená - nekorodovaná část, černá - korodovaná část). 


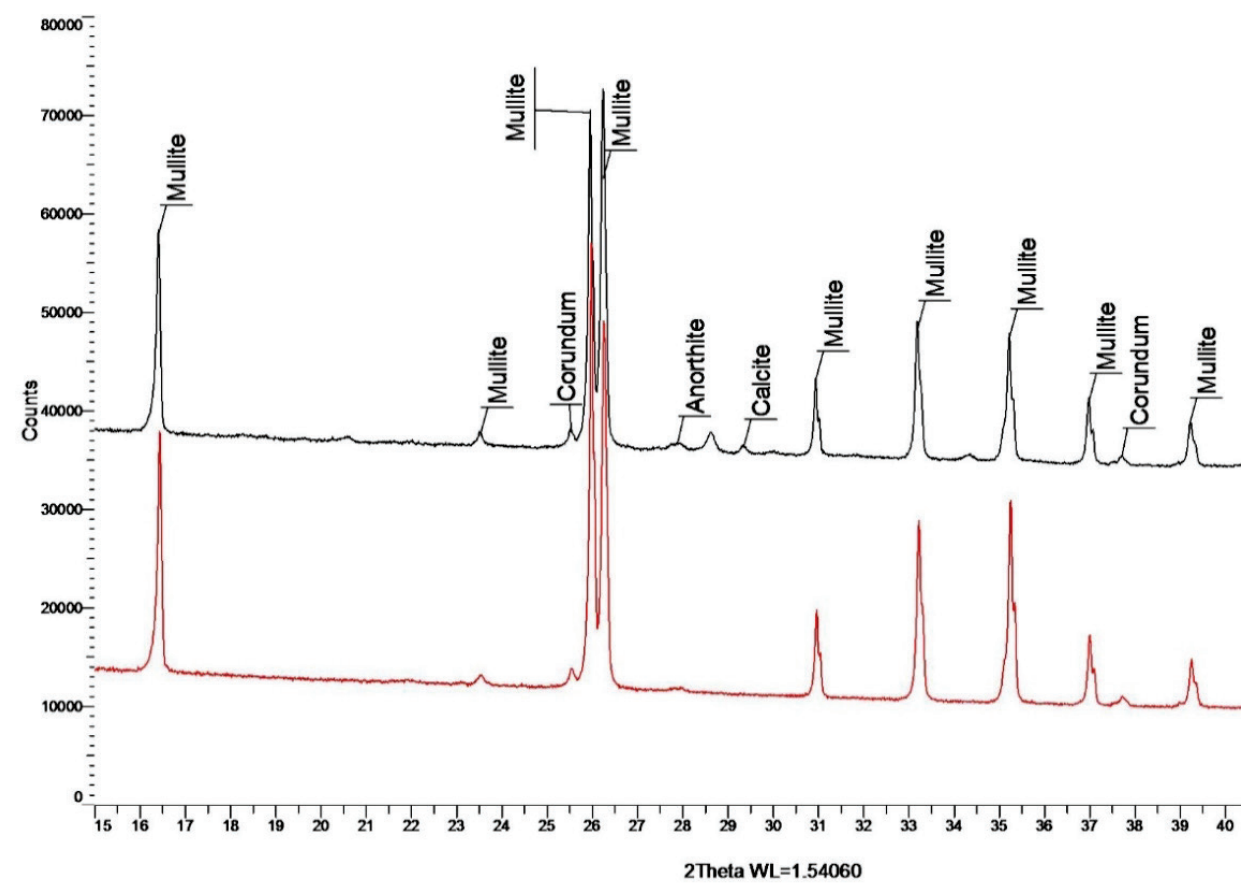

Obr. 6 LCC - difraktogramy (červená - nekorodovaná část, černá - korodovaná část).

XRD analýza na Obr. 4, Obr. 5 a Obr. 6 byla provedena za účelem zjištění krystalické struktury testovaných žárobetonů po výpalu. Hlavní krystalickou fází je mullit $\left({ }_{3} \mathrm{Al}_{2} \mathrm{O}_{3} \cdot \mathrm{SiO}_{2}\right)$ a korund $\left(\mathrm{Al}_{2} \mathrm{O}_{3}\right)$ u všech testovaných vzorků. Obsah rentgenamorfní fáze je nejvyšší pro u LCC žárobetonu. V př́ípadě výsledků u korodovaného LCC žárobetonu na Obr. 6 je ve vzorku stanoven také anorthit $\left(\mathrm{CaAl}_{2} \mathrm{Si}_{2} \mathrm{O}_{8}\right)$ a kalcit $\left(\mathrm{CaCO}_{3}\right)$. Jedná se o korozní produkty vznikající reakcí mezi hlinitanovým cementem a uhličitanem draselným. ULCC a NCC žárobetony nemají v difraktogramech tyto píky, a to z důvodu nižšího obsahu $\mathrm{CaO}$ ve směsi. Rentgenogramy všech tří korodovaných žárobetonů navíc obsahují pík $\mathrm{v}$ oblasti $28.68^{\circ} 2 \theta$. Jedná se $\mathrm{o}$ minerál richterit $\mathrm{Na}_{2} \mathrm{CaMg}_{5} \mathrm{Si}_{8} \mathrm{O}_{22}(\mathrm{OH})_{2}$. Z tohoto poznatku je zřejmé, že v př́tomnosti alkalických taviv vznikají komplexní sloučeniny.

\section{ZÁVĚR}

Tento př́íspěvek se věnuje experimentálnímu zkoušení LCC, ULCC a NCC žárobetonů. Všechny navržené žárobetony vykazují dobré fyzikální, mechanické a žárové vlastnosti. Na základě získaných výsledků je možné vyvodit několik závěrů:

- Hutnost žárobetonů je jedním z klíčových parametrů ovlivňujících nejel fyzikální, ale i žárové a korozní vlastnosti.

- Zkoušení únosnosti v žáru prokazuje nižší schopnost materiálu se snižujícím se obsahem CaO odolávat teplota při zatížení. Andalusitový LCC s hodnotou deformace $\mathrm{T}_{0.5}$ téměř $1700^{\circ} \mathrm{C}$ je možné považovat za vysoce kvalitní materiál. Žárobetony s nižším obsahem $\mathrm{CaO}$ vykazují v průměru o $50{ }^{\circ} \mathrm{C}$ než zmíněný nízkocementový žárobeton, ale na druhou stranu u dochází k nižší teplotní dilataci. V závislosti na místě aplikace žárobetonu může být vyžadována právě nižší teplotní dilatace na úkor únosnosti v žáru.

- Penetrace korozního média je u zkoumaných žárobetonů nižší se snižujícím se obsahem CaO, což je způsobeno vyšším obsahem rentgenamorfní fáze u nízkocementových žárobetonů. Korozní odolnost bezcementových žárobetonů je o 34 \% vyšší oproti nízkocementovým, a přibližně na stejné úrovni jako ultranízkocementový žárobeton. 


\section{Poděkování}

Tento příspěvek vznikl za podpory projektu Interní Grantové Agentury Vysokého učení technického v Brně, projektu specifického výzkumu číslo FAST-J-21-7489 „Studium korozní odolnosti netvarových žáromateriálů“.

\section{Použité zdroje}

[1] J. Pešek, J. Fiala, B. Korsa, L. Rybák, P. Fajfr, J. Hamáček, Bezcementové žárobetony s vazbou sol - gel. Keramický zpravodaj: Referátový časopis pro silikátový průmysl. 2008, ISSN 1210-2520.

[2] A.P. Luz, M. Braulio, V.C. Pandolfelli, Refractory Castable Engineering. Goller Verlag GmbH. 2015. ISBN 978-3-87264-004-8 734 s.

[3] L. Keršnerová, K. Lang, P. Kovář, L. Nevřivová, Improving the Properties of Refractory Materials by Sol-gel Method, in REFRA 2019, The Czech Ceramic Society.

[4] S. Kannabiran, M. Zhang, Effects of Grain Size and Temperature on the Abrasion Resistance of Low Cement Castables, in UNITECR 2017, ISBN 978-3-9815813-3-1, pp. 180-183.

[5] C. Schacht, Refractories Handbook: Corrosion of Refractories, ISBN 978-0-20302-632-8, pp. 39-79.

[6] D. Zemánek, L. Nevřivová, Use of the Sol-Gel Method for the Production of No Cement Castables. 2021, ISBN 978-0-7354-4066-1.

[7] D. Frulli, Production and Properties of Refractory Raw Materials Based on Andalusite and Mullite Influence of Impurities in the Refractory Behavior, 2016, Refractories Worldforum 8(3).

[8] D. Zemánek, L. Nevřivová, Influence of Colloidal Silica on Final Properties of No Cement Castables, 2021, Solid State Phenomena vol. 321, pp. 125-130.

[9] O.H. Borges, T.Santos Jr., V.R. Salvini, V.C. Pandolfelli, CA6-based macroporous refractory thermal insulators containing mineralizing agents, 2020, Journal of the European Ceramic Society 40(15).

[10] CEN/TS 15418 (2006) (en). Methods of test for dense refractory products - Guidelines for testing the corrosion of refractories caused by liquids. 